\title{
EFEKTIFITAS SPRAY EKSTRAK DAUN LAMTORO (LEUCAENA LEUCOCEPHALA) TERHADAP JUMLAH DAN WAKTU KEMATIAN CAPLAK RHIPICEPHALUS SANGUINEUS PADA ANJING
}

\author{
Olan Rahayu Puji Astuti Nussa \\ Laboratorium Histologi Veteriner, Fakultas Kedokteran Hewan \\ Universitas Wijaya Kusuma Surabaya \\ lord_shyn@yahoo.co.id
}

\begin{abstract}
This study aims to test the effectiveness of using Spray Extract Leucaena Leaf (Leucaena leucocephala) on dogs with Tick Rhipicephalus sanguineus.

The method used is an experimental design with Group Random Design (GRD), with the number of sample 8 dogs of different ages and sex. Samples were divided into four treatments and two replications.

Data analysis techniques used in this study is the Analysis of Variance (ANOVA), with an examination of macroscopic was conducted by observing the amount and time of death Ticks Rhipicephalus Sanguineus in dogs were carried out on the day of observation $7^{\text {th }}, 14^{\text {th }}$ and $21^{\text {st }}$.

The results of the study with $\alpha=5 \%$ concluded that: (1) Based on the results of one way ANOVA test in the experimental group, showed that the influence of leaf extract dose leuceana to the number of ticks deaths; Based on the observation time, there is the influence of observation time to the number of ticks. (2) $F$ count $>F$ table $=129.7(P<0.05)$ showed that the treatment group of dogs were given the extract leuceana leaf spray dose 60\% (P3) and most effective when compared with those dogs from the negative control group without treatment (PO), a group treated extract leuceana leaf spray dose of $20 \%$ (P1), and a group treated extract leuceana leaf spray dose of $40 \%$ (P2).
\end{abstract}

Keywords: Spray Extract Leucaena Leaf (Leucaena leucocephala), tick Rhipicephalus sanguineus.

\section{PENDAHULUAN}

Di Indonesia, hewan sering dijadikan peliharaan atau hewan kesayangan. Hewan peliharaan berbeda dari hewan ternak, hewan percobaan, hewan pekerja atau hewan tunggangan yang dipelihara untuk kepentingan ekonomi atau untuk tugas tertentu. Hewan peliharaan yang populer biasanya adalah hewan yang memiliki karakter setia pada majikannya atau memiliki penampilan yang menarik, atau kemampuan menarik tertentu seperti mengeluarkan suara yang indah. Salah satu kelas hewan kecil yang sering dijadikan hewan peliharaan adalah kelas mamalia, seperti anjing, kucing, kelinci, hamster Syirian dan lain-lain.

Negara Indonesia merupakan negara yang sangat kaya akan pemanfaataan obatobatan yang berasal dari alam (obat herbal) juga telah banyak terbukti dan teruji kemanjurannya untuk terapi pengobatan terhadap penyakit. Tanaman lamtoro (Leucaena leucochepala) termasuk leguminoseae yang tergolong dalam subfamili mimosaceae, banyak mengandung bahan aktif obat-obatan berupa : Alkaloid, Saponin, Flavonoid, Tanin, Mimosin, Leukanin, Protein, Asam lemak dan Serat.

Hewan kesayangan banyak mengalami gangguan,khususnya pada kulit dikarenakan bakteri, virus, parasit dan jamur. Untuk itu dilakukan penelitian dengan menggunakan bahan tradisional (obat herbal) daun lamtoro yang di ekstrak untuk membunuh parasit caplak Rhipicephalus sanguineus yang sering pada anjing kecil maupun anjing dewasa, hal ini sangat mengganggu aktivitas hewan kesayangan ini. 


\section{METODE PENELITIAN}

Bahan penelitian adalah Anjing jantan/betina sebanyak 8 ekor, kandang, pakan anjing, mikroskop, daun lamtoro, etanol absolut, aquadest steril, pinset, sisir serit, cawan petri, botol spray $100 \mathrm{ml}$, kertas saring, penyaring, waterbath, aquadest steril, dan minyak tanah.

Penelitian dilaksanakan pada bulan Nopember 2015 hingga Desember 2015 di Laboratorium Farmakologi dan Farmasi Universitas Wijaya Kusuma Surabaya, Fakultas Farmasi Universitas Airlangga, dan kandang Klinik Hewan Aneka Satwa di Surabaya.

Prosedur Penelitian

1. Pembuatan Ekstrak Daun Lamtoro 2000 gram serbuk daun lamtoro, lalu dimasukkan ke dalam labu/tabung ekstraksi dan direndam dengan pelarut etanol dengan perbandingan tinggi serbuk dan pelarut $1: 3$. Larutan ini harus dikocok sesering mungkin dan setelah 48 jam larutan tersebut disaring dengan kertas saring. Ekstrak etanol daun lamtoro yang diperoleh selanjutnya dievaporasi dengan menggunakan vacuum rotary evaporator pada suhu maksimum $40^{\circ} \mathrm{C}$ hingga diperoleh ekstrak kental (Syahidah, 2008 ; Marisi dkk., 2010)

2. Pembuatan bentuk sediaan obat spray ekstrak daun lamtoro.

Ekstrak daun lamtoro kental yang sudah ditimbang 50mg kemudian ditambahkan $50 \mathrm{mg}$ vehikulum aquadest steril untuk membuat spray ekstrak daun lamtoro. (Joenoes, 2010)

3. Perlakuan pada hewan coba

Anjing jantan/betina 8 ekor, dibagi 4 kelompok perlakuan, dan 2 ulangan, sebagai berikut kelompok anjing sebagai kontrol/tanpa diobati (P0), kelompok yang diobati spray ekstrak daun lamtoro dosis $20 \%$ (P1), kelompok yang diobati spray ekstrak daun lamtoro dosis 40\% (P2), kelompok yang diobati spray ekstrak daun lamtoro dosis $60 \%(\mathrm{P} 3)$.

Anjing sebanyak 8 ekor diinfestasikan caplak Rhipicephalus Sanguineus sebanyak 70-80 ekor dibiarkan selama 1-2 minggu agar infestasi menyebar rata ke seluruh permukaan kulit. Setelah 1-2 minggu daerah infestasi terlihat merata, diberikan pengobatan dengan bentuk sediaan obat sesuai perlakuan dengan dosis $20 \%, 40 \%$ dan $60 \% 2$ kali sehari selama 21 hari.

4. Pemeriksaan secara makroskopis dilakukan dengan metode pengamatan terhadap jumlah dan waktu kematian caplak Rhipicephalus Sanguineus pada anjing dilakukan pada hari pengamatan ke-7, ke-14 dan ke-21 (Entjang, 2006)

\section{HASIL DAN PEMBAHASAN}

Berikut ini hasil pemeriksaan jumlah caplak yang diberi ekstrak lamtoro dan kontrol:

Tabel 1. Nilai Rerata pemeriksaan jumlah kematian caplak Rhipicephalus Sanguineus seluruh kelompok (P0), lamtoro 20\% (P1), lamtoro 40\% (P2), dan lamtoro 60\% (P3).

\begin{tabular}{|c|c|c|c|c|}
\hline $\begin{array}{c}\text { Hari } \\
\text { Ke- }\end{array}$ & (P0) & (P1) & (P2) & (P3) \\
\hline 7 & 0 & 0 & 1 & 1 \\
\hline 14 & 1 & 6 & 25 & 45 \\
\hline 21 & 6 & 28 & 50 & 88 \\
\hline
\end{tabular}

Setelah dianalisis dengan statistik ANOVA menunjukkan hasil pengamatan pada hari ke-7, ke-14 dan ke-21, F hitung $>\mathrm{F}$ tabel $=129,7$ $(\mathrm{P}<0,05)$. Hal ini berarti kelompok anjing yang diberikan pengobatan spray ekstrak daun lamtoro dosis $60 \%$ (P3) paling baik dan efektif jika dibandingkan kelompok anjing dari kelompok kontrol negatif tanpa diobati (P0), kelompok yang diobati spray ekstrak daun lamtoro dosis $20 \%$ (P1), dan kelompok yang diobati spray ekstrak daun lamtoro dosis $40 \%$ (P2). Berdasarkan Hasil uji one way anova pada kelompok perlakuan, menunjukkan bahwa adanya pengaruh dosis ekstrak daun lamtoro terhadap jumlah kematian caplak ( $<\square 0,05$ ). 
Berikut ini gambar grafik jumlah kematian caplak :

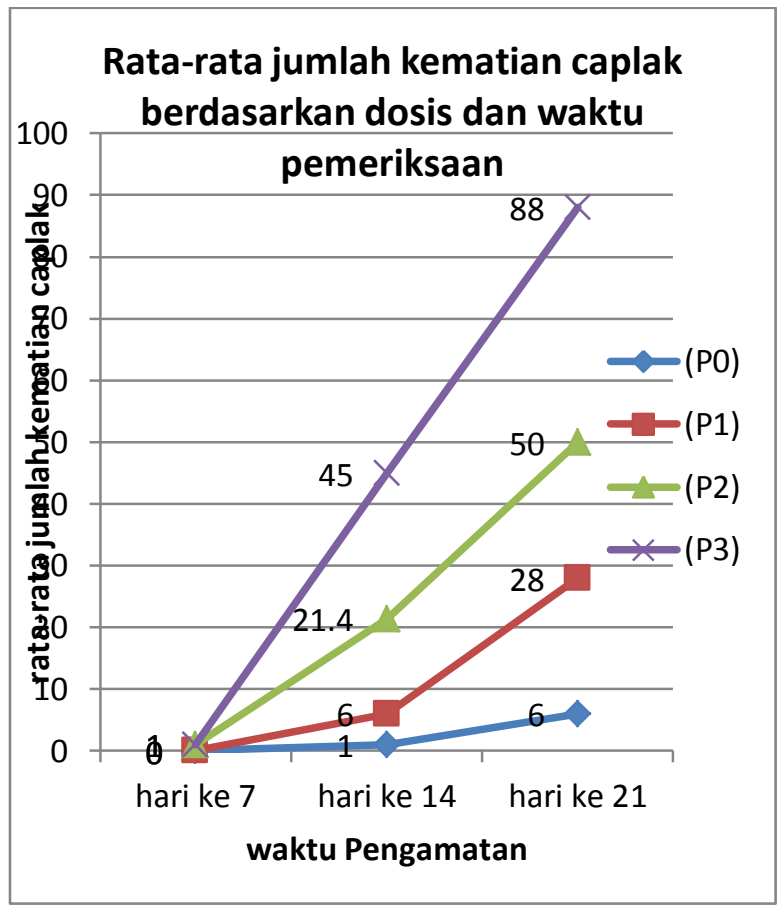

Gambar 1. Grafik Nilai Rerata pemeriksaan jumlah kematian caplak Rhipicephalus Sanguineus antara kelompok anjing sebagai kontrol / tanpa diobati (P0), kelompok diobati spray ekstrak daun lamtoro 20\% (P1), kelompok diobati spray ekstrak daun lamtoro $40 \%$ (P2),kelompok yang diobati spray ekstrak daun lamtoro $60 \%$ (P3).

Berdasarkan waktu pengamatan, ada pengaruh waktu pengamatan terhadap jumlah caplak ( $<\square 0,05)$. Interaksi dosis dan waktu pengamatan berpengaruh terhadap jumlah caplak ( $p<\square 0,05)$. Hal ini disebabkan komponen bahan aktif turunan Fenol (tanin), turunan Alkaloid dan turunan Flavonoid yang terdapat di dalam ekstrak daun lamtoro sangat efektif sebagai anti bakteri, anti jamur dan anti parasit. Kandungan zat aktif di dalam ekstrak daun lamtoro tersebut mampu menghambat metabolisme karbohidrat, protein, dan lemak serta melisiskan dinding sel caplak Rhipicephalus Sanguineus sehingga pertumbuhan maupun perkembangannya dapat dihambat dan mengakibatkan kematian caplak anjing. Selain itu kandungan senyawa Flavonoid dan alkaloid mampu mengadakan hambatan terhadap impuls serabut-serabut syaraf di bagian pusat syaraf caplak Rhipicephalus Sanguineus sehingga caplak berhenti bergerak dan beraktivitas kemudian terjadi kematian caplak tersebut. Hal ini dapat diamati secara makroskopis pada hari pengamatan ke-14 hingga hari ke-21. (Becker, 2010, Khairun D dkk., 2012, Wulandari, 2014). Spray ekstrak daun lamtoro dengan vehikulum aquadest steril berfungsi memudahkan dan mengoptimalkan mekanisme kerja obat untuk mencapai target sasaran predileksi parasit di bagian superficial/permukaan kulit maupun di bawah permukaan kulit (Joenoes, 2010). caplak:

Berikut ini gambar makroskopis jumlah

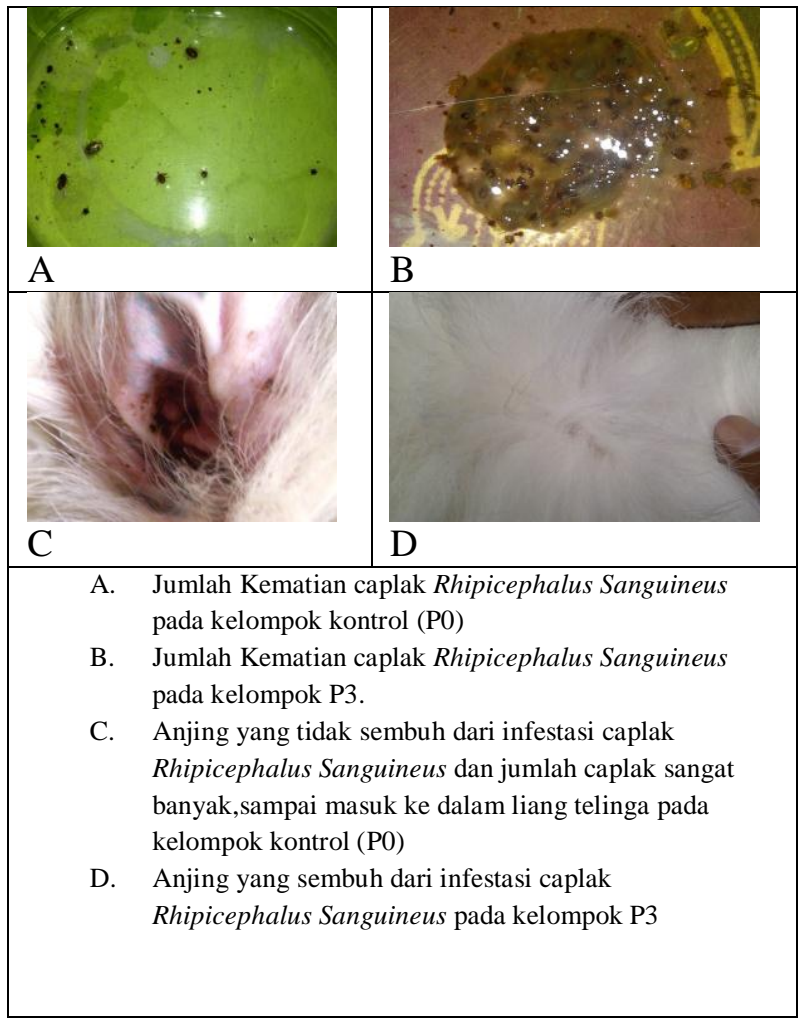

Jumlah caplak semakin banyak yang terdapat di dalam liang telinga dan bagian tubuh anjing yang lain pada kelompok kontrol, disebabkan karena kelompok kontrol tidak diberikan terapi pengobatan dengan obat spray tersebut. Tanpa adanya terapi pengobatan terhadap caplak secara tepat, cepat dan rutin menyebabkan pertumbuhan dan perkembangan caplak semakin besar dan mudah menyebar ke seluruh bagian tubuh anjing pada kelompok 
kontrol. Petumbuhan dan penyebaran caplak yang tidak segera diobati dan dikendalikan dikuatirkan dapat menyebabkan kematian pada anjing, bisa menular dan menimbulkan gatalgatal ataupun alergi pada manusia (Entjang, 2006; Wardhana,dkk., 2006). Olehkarena itulah spray ekstrak daun lamtoro merupakan salah satu alternatif yang cukup murah, bahan baku obatnya mudah diperoleh, dan relatif aman dipergunakan sebagai terapi pengobatan caplak Rhipicephalus Sanguineus pada anjing.

\section{KESIMPULAN}

1. Spray ekstrak daun lamtoro dosis $60 \%$ paling baik dan efektif digunakan untuk menghambat pertumbuhan dan membunuh caplak Rhipicephalus Sanguineus pada hari pengamatan ke-21.

2. Spray ekstrak daun lamtoro sebagai obat kutu/caplak yang relatif murah, mudah dan aman diberikan pada hewan kesayangan (anjing)

\section{SARAN}

1. Perlu penelitian lebih lanjut dengan pemeriksaan kesembuhan dan kematian caplak Rhipicephalus Sanguineus secara molekuler dengan alat PCR atau LC-ESI MS.

2. Perlu penelitian lebih lanjut dengan pemeriksaan darah lengkap (eritrosit dan leukosit) untuk memastikan diagnosa kesembuhan pasien dari infestasi caplak Rhipicephalus Sanguineus

\section{DAFTAR PUSTAKA}

Becker K, 2010. Apicomplexan Parasites: Molecular Approaches toward Targeting Drug Development. Germany : Wiley - Blackwell. Vol 2. No $1: 3-20$.

Entjang I., 2006. Mikrobiologi dan Parasitologi. Penerbit PT. Citra Aditya Bakti. Bandung. Cetakan ke-4. ISBN : 979-414-849-0.

Joenoes, N.Z., 2010. Ars Prescibendi Resep Yang Rasional 2. Airlangga University Press. Surabaya.
Khairun D , Ni'maa, Subakir, and Suhardjono., 2012. Comparison of Skin Extract Mangosteen (Garcinia Mangostana Linn) with $2 \%$ Ketokonazole Inhibits

Growth Pityosporum Ovale on Dandruff. Hasil Laporan Penelitian Dosen Fakultas Kedokteran Universitas

Diponegoro Semarang, 2012.

Siswandono, 2014. Phytochemistry. Pengembangan Obat Baru. Departemen Kimia Medisinal. Fakultas Farmasi. Universitas Airlangga. Surabaya.

Subronto, 2006. Penyakit Infeksi Parasit \& Mikroba pada Anjing \& Kucing. Gadjah Mada University Press. Yogyakarta.

Syahidah, 2008. Bioaktivitas Zat Ekstraktif Kayu Manggis (Garcinia Mangostana L.) Terhadap Rayap Tanah Coptotermes Curvignathus Holmgren. Sekolah Pascasarjana Institut Pertanian Bogor. Bogor.

Wardhana, A. Manurung J, dan Iskandar T., 2006. Tantangan Penyakit Zoonosis Masa Kini dan Masa Datang. Wartazoa.Vol. 16. No 1: 40-52.

Wulandari S, 2014. Pengaruh Perbedaan Dosis Salep Ekstrak Daun Lamtoro ( Leucaena Leucochepala ) Terhadap Penyembuhan Luka Insisi Pada Hamster (Mesocricetus Auratus. Fakultas Kedokteran Hewan Universitas Wijaya Kusuma. Surabaya. 